\title{
Transnationalism and the
}

\section{League of Nations:}

\section{Understanding the Work of Its}

\author{
Economic and Financial
}

\section{Organisation}

PATRICIACLAVIN AND JENS-W ILHELM WESSELS

\begin{abstract}
This article explores the work of the little-studied Economic and Financial Organisation of the League of Nations. It offers a sustained investigation into how this international organisation operated that assesses the transnational aspects of its work in relation to its inter-governmental responsibilities, and demonstrates the wide-ranging contribution of the organisation's secretariat. The second part of the article establishes the way in which transnationalism enabled the United States, the League's most influential non-member, to play a crucial role in shaping the policy agenda of the League. It also shows how a growing sense of frustration in its work prompted EFO to attempt to free itself from inter-governmental oversight and become an independent organisation to promote economic and financial co-operation in 1940 - a full four years before the creation of the Bretton Woods agreements.
\end{abstract}

Writing in I933, the British journalist Beverley Nicols, reflected that 'never yet have I read anything whatever about the League of Nations which was not unutterably boring'. ${ }^{1}$ Both during Nichols's day and since, it was the political work of the League, notably focused on the issues of disarmament and the treatment of minorities, which attracted the most attention. While this work went into sharp decline during the crisis decade of the I930s, the one agency of the League that consistently grew in size and ambition was the Economic and Financial Organisation (EFO). It was the

Patricia Clavin, Jesus College, Turl St, Oxford, OXI 3DW, UK. patricia.clavin@jesus.ox.ac.uk. Financial support for research on this paper from the AHRC Grant No. B/RG/AN4009/APNI2550 is gratefully acknowledged.

1 Beverley Nichols, Cry Havoc! (London: Jonathan Cape, I933), I23. 
world's first inter-governmental organisation dedicated to promoting economic and monetary co-operation. Despite its pioneering remit, surprisingly little of its history is known. This article, conceived as part of a wider study of EFO's work, offers the first sustained account of EFO's internal structure. Why is it important to understand how the organisation operated? The answer, in large part, is because it is a useful vantage point from which to consider not only EFO's work, but also that of other 'technical' agencies of the League and the performance the League as a whole. As has been noted elsewhere, the issue of how international organisations as a whole actually work (as opposed to how they claimed they function) is a hugely under-researched topic. ${ }^{2}$ Only when more is known about how they operate will it be possible to assess effectively the contribution of international organisations to the history of relations between and within nation-states.

The study of international organisations has recently come back into vogue. With social and cultural questions to the fore, the new history writing of international organisations sees them as a historical site through which to investigate the intersecting historiographies that include feminism, civil rights, health care and welfare. The interest of scholars of these disciplines coincides with the trend, evident among cultural historians in particular, to attempt to bypass or transcend the nation as the focus of study. Here the language of transnationalism dominates. The style is rather different from that taken in social science, which, of course, has a long history of engaging with the role of international organisations in world politics. Here the approach is primarily a functional one, focused on the utility of international organisations and their relation to other institutions, notably the nation-state, in the world polity. In common with social and cultural historians, social scientists have largely come to reject the view that international organisations are autonomous actors in world politics, but the primacy of the nation-state in their analyses remains clear: international organisations remain primarily an instrument through which nation-states seek to wield power in international relations. International organisations are only seen to have autonomy on so-called 'technical' issues, such as health care, because they are seen to enjoy a largely non-political remit. ${ }^{3}$ But as the work of the Economic and Financial Organisation reveals, the border between 'technical' and 'political' issues was an indistinct one. When it came to EFO's efforts to combat protectionism and promote co-ordinated currency devaluation in 1935 and 1936 - an example of its work explored in this article - while

2 Barbara Koremenos, Charles Lipson and Duncan Snidal, 'The Rational Design of International Institutions', International Organization, 55, 4 (200I), 76I. The point is also made by Susan Strange in 'Why Do International Organizations Never Die?', in Bob Reinalda and Bertjan Verbeek, eds., Autonomous Policy Making by International Organizations (London: Routledge, I998), 2I4-2 I6. Northedge's widely used text is poor at differentiating the components of any League division. See, e.g., his treatment of EFO in F. S. Northedge, The League of Nations. Its life and times 1920-1946 (Leicester: Leicester University Press, I986), I69-74.

3 Michael N. Barnett and Martha Finnemore, 'The Politics, Power, and Pathologies of International Organizations', International Organization, 53, 4 (I999), 699-732; Clive Archer, International Organizations, 3 rd edn (London: Routledge, 2003), 68-73. 
League officials sought to hide behind the distinction, they certainly did not believe in it. ${ }^{4}$

Particularly significant for the concerns of this theme issue is the fact that the history of the Economic and Financial Organisation challenges the tendency to regard inter-governmental, transnational and non-governmental organisations as closed categories. Published studies of the League, for example, frequently labour under the misapprehension that it was solely an international (i.e. inter-governmental) organisation. Yet the structure and work of EFO draws out the degree to which internationalism, transnationalism and multi-nationalism coexisted within the same organisation. It was precisely this mix which allowed EFO to make a significant contribution to the development of economic and financial relations in the long run.

The multinational, or alternatively multi-cultural, dimension of the League's work came from its personnel. Writers of transnational history frequently emphasise its social quality but, to date, the permeable property of transnational encounters has made little impact on analyses of personnel working for international organisations, who have been characterised largely as continuing to support the interests of their originating nation-state inside any given international institution. ${ }^{5}$ If officials are assessed to have been in some way absorbed into the fabric of the international organisation, their position is identified more as an agent preoccupied with the expansion of his or her section's resources than as men and women dedicated to strengthening the position of their international institution and its efforts to shape international policy from its particular perspective. ${ }^{6}$ As the international history of EFO in the I930s reveals, such tidy characterisations - the League official as self- and nation-serving actor - are problematic.

The article draws out the degree to which League officials sought to prioritise League interests over those of the nation-states from which they originated, and demonstrates that the secretariat of EFO, notionally there to serve the interests of League members represented in the Assembly and the Council, developed its own policy agenda for the promotion of international co-operation that sometimes ran counter to the interests of its major national sponsors. In short, it aims to demonstrate that EFO played a distinctive role in the international and transnational relations of the period. Here, the United States holds a pivotal position. A careful reconstruction of how EFO worked reveals how this key non-member state, represented in neither the Council nor the Assembly of the League, nonetheless came to play a key role in EFO's work by the I930s. The discovery sheds interesting light on a hitherto unstudied aspect of US internationalism in the I93Os. The absorption of US personnel

4 Bertjan Verbeek, 'International Organizations' The ugly duckling of international relations theory?', in Reinalda and Verbeek, Autonomous Policy Making, I6. The recent preoccupation with epistemic communities in international relations reinforces the latter view. See the seminal work of Peter M. Haas, ed., Knowledge, Power, and International Policy Coordination (Columbia: University of South Carolina Press, I997).

5 See, e.g., Hadewych Hazelzet, 'The Decision-Making Approach to International Organizations. Cox and Jacobson's Anatomic Lesson Revisited', in Reinalda and Verbeek, Autonomous Policy Making, 27-4I.

6 Verbeek, 'International Organizations', 22. Archer, International Organizations, 7I-2. The first studies offered a forceful realist critique. 
and concerns into this assessment of EFO's structure and policy preoccupations, represents EFO as a platform through which three distinct, yet interconnected actors the Secretariat, member states, and influential non-member states - sought to shape international relations of the period.

The title of the League in French, the second official language of the League, was the Société des Nations, and the term 'society' goes some way to capturing the diffuse structure of the institution which proved itself to be creative and flexible in the face of the enormous challenges it faced in the I930s. (Quite how successful its policy agenda was in addressing the diplomatic challenges before the League of Nations and its key proponents in the I930s is, necessarily, another question for another time.) Unravelling the way in which this society operated takes up the first three sections of the article, where we set out the various elements that made up EFO and how they worked. The next two sections expatiate on the way in which, during the I930s, the secretariat of EFO, notionally that division of the League intended to serve the interests of nation-states, exploited the structure of the League to pursue its own policy agenda on pursuing seemingly technical questions that, to its mind, were intimately connected with pressing issues of high policy. As a result, the nonintergovernmental elements of the League of Nations became more than a stage, with the secretariat served as willing and able stagehands; they sought to write the script and provide the actors too.

\section{The Economic and Financial Organisation}

Akira Iriye's recent account of the League's contribution to the emergence of a global community is but the most recent example of a widespread failure by international historians to recognise the economic and financial dimension of the League's work. ${ }^{7}$ The tone was set by early histories of the League, which frequently and incorrectly dismissed EFO as 'the greatest failed organisation of the League'. ${ }^{8}$ With the archives of EFO largely untouched, this verdict was based on a misunderstanding of both how EFO worked and its place within the machinery of the League. ${ }^{9}$ It is only recently

7 A. Iriye, Global Community. The Role of International Organisations in the Making of the Contemporary World (Berkeley and Los Angeles: University of Los Angeles Press, 2002), 2 I.

8 David Armstrong, The Rise of the International Organisation. A Short History (London: Macmillan, I982), 27. This characterisation is echoed by F. S. Northedge and M. J. Grieve, A Hundred Years of International Relations (London: Duckworth, I97I), and in Charles Henry Alexandrowicz, International Economic Organisations (London: Stevens, I952), 76, I Io. The more recent work by Victor-Yves Ghebali, 'The League of Nations and Functionalism', in A. J. R. Groom and Paul Taylor, eds., Functionalism. Theory and Practice in International Relations (London: University of London Press, I975), I4 I-6I, offers only a very brief account of EFO's structure and functions.

9 A more accurate picture of the structure of the League can be gleaned from accounts written by the men and women who worked for it, although these can be opaque to the non-specialist. The best is William Martin Hill, The Economic and Financial Organisation of the League of Nations. A Survey of Twenty-five Years' Experience (Washington, DC: Carnegie Endowment for International Peace, I946) (Hill was a member of section of the Under-Secretaries-General Offices). For details of the League Secretariat, see Denys P. Myers, Handbook of the League of Nations; A Comprehensive Account of its Structure, Operation and Activities (New York: World Peace Foundation, 1935) and Egon RanshofenWertheimer, The International Secretariat. A Great Experiment in International Administration (New York: 
that economists and economic historians have become interested in exploring EFO's work. Pauly and De Marchi were among the first to attempt to explore the longerterm contribution of the Economic and Financial Organisation's commitment to the collection and dissemination of data, and later ideas, to the history of both economic thought and policy developments in the middle of the twentieth century; further contributions were made by Ghebali, Dubin and Menzies. ${ }^{10}$ But many of EFO's activities and its contribution to international economic relations in that period remain to be chronicled - its contribution to the I936 Tripartite Stabilization Agreement, the wide-ranging work of the Depression Delegation, the efforts of the Raw Materials Committees and its central role in shaping the work of the United Nation's Relief and Rehabilitation Administration after the end of the Second World War. But first we need an accurate and sustained account of how the organisation operated. Only by avoiding the well-rehearsed question of whether EFO was a 'failure' or 'success' are we able to avoid the invariable discussion of the performance of member states that comprise much of the writing on the League, and to move the history of EFO into a transnational setting.

The structure of EFO, and to a large extent of the League in general, has been widely misunderstood. It is easy to see why. The League's organisations comprised a wide variety of bodies that were reorganised and renamed a number of times. Its nomenclature confused all but its own officials, consisting as it did of various 'committees', 'sub-committees', 'delegations', 'commissions', 'sections', 'organisations' and 'services' (as noted above, this confusion persists in the published literature). Nor do the League's own publications facilitate understanding of its work.

Carnegie Endowment for International Peace, Klaus Reprint Co., I972 [I945]) (Wertheimer was a member of the Social Questions Section). Vladimir D. Pastuhov, Memorandum on the Composition, Procedures and Functions of Committees of the League of Nations (Washington, DC: Carnegie Endowment for International Peace, I943) (Pastuhov was a Czechoslovakian member of the Opium Traffic Section). For a list of members of section see League of Nations, The Official Journal of the League of Nations, Geneva, October 1937, 793 and 805. There are also a number of short studies released during the war as part of the 'educational' drive to help establish the new United Nations. See The Committees of the League of Nations. Classified list and essential facts (Geneva, I945); Elisabeth M. Langer, League of Nations List of Commissions and Committees, Economic and Financial Section. Prepared under the direction of Laura S. Turnbull (New York: Woodrow Wilson Foundation Memorial Library, I946).

10 See Louis W. Pauly, 'The League of Nations and the Foreshadowing of the International Monetary Fund', Essays in International Finance, No. 201, December 1996, I-52, and Neil de Marchi, 'League of Nations Economists and the Ideal of Peaceful Change in the Decade of the "Thirties", in Craufurd D. Goodwin, ed., Economics and National Security. A History of Their Interaction. Annual Supplement to Volume 23, History of Political Economy (London: Duke University Press, I99I), I43-78. Dubin's work usefully outlines the League's contribution to economic appeasement. See Martin D. Dubin, 'Toward the Bruce Report: the Economic and Social Programs of the League of Nations in the Avenol era', in Graduate Institute of International Studies, ed., The League of Nations in Retrospect: Proceedings of the Symposium organized by the United Nations library and the Graduate Institute of International Studies (Geneva: Berlin de Gruyter, I983), 42-72. Menzies's work explores the early origins of EFO, notably the activities of the Economic Committee, in the early I920s: A. Alexander Menzies, 'Technical Assistance and the League of Nations', The League of Nations in Retrospect, 295-3 I2. Jean Siotis's examination is short and contains a number of errors. See Jean Siotis, 'The Institutions of the League of Nations', The League of Nations in Retrospect, I9-4I. The best overview of literature on the League as a whole can be found at http://www.indiana.edu/ league/bibd.htm. 
Some of the confusion was sown deliberately by EFO itself. Although born of grand claims to 'open diplomacy', when it came to sensitive matters of economic and financial diplomacy it was especially important that representatives of nation-states, which sought to promote policies and forge agreements through EFO, believed their discussions to be confidential. The opaque structure of the League assisted this task. The official, published minutes, resolutions and reports of the various EFO committees and sub-committees and the League Secretariat reflected legal formalities and conventions, as well as institutions, and were crafted with an eye to political sensibilities. $^{11}$

When the League was founded in I9I9, economic and financial questions were given little consideration, the Covenant making only vague references to economic and social policy. ${ }^{12}$ This was not so much an oversight as a reflection of continued international tensions, notably between the former Allied powers, over economic and financial policy, particularly with regard to reparations and war debts. Contemporary economic thought, too, played a part. When it came to trade and monetary policy almost everyone envisioned a quick return to the pre-war world economy, a world in which national governments played but the most minimal role. Where international co-operation was necessary, it was believed that the lead should be taken by independent central banks of the world's major economies - the United States, Britain, France and Germany. There was no place here for the potential anarchy that might be unleashed by allowing the polyglot League into such a sensitive area of policy-making, where one false move, so the reasoning went, had the potential to trigger financial and economic instability around the world.

But the difficult economic environment in which nation-states found themselves by 1920 quickly challenged these assumptions about international economic and monetary diplomacy. The continued economic dislocation of central Europe, the infectious problem of rising inflation and the end of the wartime boom starkly illustrated that the European economy, in particular, was not likely to right itself after the war without some kind of international co-operation. As a result, member states of the League did not oppose its proposal to create an Economic and Financial Section within its Secretariat. ${ }^{13}$ The initial focus of the section's work was to collate economic statistics. In this form, the Economic and Financial Section had neither the remit nor the power to formulate policy recommendations (although its data

11 Several scholars have identified similar features in UN reports and resolutions. Peter R. Baehr and Leon Gordenker have called UN resolutions 'impenetrably complex'. Peter R. Baehr and Leon Gordenker, The United Nations in the 1990s (London: Macmillan, I992), 25. On the often stylised nature of UN meeting records, reports and notes see Anthony Mango, 'The Role of the Secretariats of International Institutions', in Paul Taylor and A. J. R. Groom, eds., International Institutions at Work (London: Pinter Publishers Limited, I988), 43-5. For a lucid overview, see David Armstrong, Lorna Lloyd and John Redmond, From Versailles to Maastricht. International Organisation in the Twentieth Century (Basingstoke: Macmillan, I996).

12 See Art. 23 of the Covenant, in John Fischer Williams, Some Aspects of the Covenant of the League of Nations (London: Humphrey Milford, Oxford University Press, I934, 277-9). See also Ghebali, 'League of Nations and Functionalism', I46, and Menzies, 'Technical Assistance', 295.

13 Alfred Zimmern, The League of Nations and the Rule of Law 1918-1935 (London: Macmillan, I939), 320 ff.; Martin Dubin, 'Transgovernmental Processes in the League of Nations', International Organization, 37, 3 (I983), 485-489. 
often informed the policy choices of governments), had little direct contact with governments and certainly posed no threat to nation-states' perceived interest in formulating and implementing economic and monetary policy as they saw fit.

Early on, however, the officials of the Economic and Financial secretariat demonstrated ambition and independence of mind by pressing for the creation of an independent expert advisory committee on economic and financial questions to help the Assembly and the Council and fortify the role of the League in the world economy. ${ }^{14}$ The officials of the Economic and Financial secretariat (or section) argued for an expanded technical institution that, supported by a dedicated, skilled secretariat, would have the power to develop and advocate particular policies to member and non-member states. The proposal for an expanded economic and financial organisation was discussed at the first meeting of the Assembly in I920, when the British government emerged as the greatest critic. Britain's position revealed both the common concern of the major powers that such a body would severely impinge on its national sovereignty, and its particular worry that international expectations of British economic internationalism were more than it could satisfy in the aftermath of the war. Financial circles in Britain were anxious that an expansion of League involvement in economic and financial policy would facilitate criticism of its economic and financial policies by other nations. ${ }^{15}$ Despite these anxieties, however, Britain also recognised the benefits of international co-operation for its national interests, given the growing problems before the world economy and the lack of real progress at the International Financial Conference held in Brussels in I920. It was here that a significant step in the development of transnational relations emerged, for, in a resolution characteristic of the bankers' diplomacy that was to mark financial relations in the decade, the Brussels meeting established a 'committee of bankers and businessmen to frame measures to give effect to certain decisions of the Conference'. ${ }^{16}$ The newly constituted Joint Provisional Economic and Financial Committee was officially not an intergovernmental forum but a body made up of 'independent experts' nominated by the Council of the League. Committee members could originate from member or nonmember states, but were not official representatives of their national governments. It was deliberately kept unclear if the 'experts' were to be bankers, businessmen, politicians or civil servants.

Member as well as non-member states immediately recognised the importance and novelty of the Joint Provisional Economic and Financial Committee. The committee identified questions of central importance to the formulation and implementation of national economic and monetary policy in a public forum, and its findings were published and legitimised by the League. Its operations were to stand in marked contrast to the secrecy that surrounded bankers' diplomacy which dominated the way in which countries negotiated their return to the gold standard in the I920s. In the first place, the need for consensus and public accountability, coupled with the

14 Menzies, 'Technical Assistance', 296.

15 Ghebali, 'League of Nations and Functionalism', I 50.

16 League of Nations, The Committees of the League of Nations. Classified List and Essential Facts (Geneva, I945), 37 . 
sensitivity of the issues under the discussion, meant that member states' governments and central banks treated the new committee with caution. They were careful to appoint experts who represented the government's view in preference to those who took a more independent line, and there was certainly no question that the League would query or reject their appointees. ${ }^{17}$ The word 'provisional', used to temper the concerns of member states who feared League encroachment on their powers, was dropped in I923, when the committee was given permanent status and divided into two distinct organs: the Economic Committee and the Financial Committee. ${ }^{18}$ These committees became central to the work of EFO because they were the only inter-governmental bodies that had an exclusive mandate to examine economic and monetary questions and to publish policy recommendations aimed at the Assembly and the Council. They also sought to disseminate their work to as many non-member state governments as possible as well as the public (informed and uniformed) at large.

So-called 'independent experts' were seconded to the Economic and Financial committees as a result of informal, behind-the-scenes negotiations between the officials of the Economic and Financial Section and governments of the primary League member states. A survey of committee membership in the inter-war period brings out the degree to which membership mirrored that of the nation-states who had permanent seats on the Council. (This is no surprise given that the Council controlled the process by which members were nominated.) ${ }^{19}$ The remainder of the committees' members came from smaller, usually European, member states. ${ }^{20}$

The most significant sign of committees' growing importance, however, came in 1927 when the United States agreed to participate in its work. Needless to say, US officials were not to be found in the Economic and Financial sections nor in the Second Committee, but thanks to the sustained efforts of the State Department and the Economic and Financial Section the world's new economic powerhouse was represented on the Economic and Financial Committees as well as on special subcommittees. ${ }^{21}$ This remained the case until the Economic and Financial Committees were formally dissolved with the inauguration of the United Nations in I945.

17 See Menzies, 'Technical Assistance', 296. Government officials, of course, were at pains to point out publicly that governments did not designate committee members, but attended in their personal capacity as experts. See, e.g., F. A. Van Woerden, La Société des Nations et Le Rapprochement Economique International (The Hague: Martinus Nijhoff, I932), I3.

18 Council resolution from Io Sept. I923. League of Nations, Committees of the League of Nations, 37. See also Wertheimer, International Secretariat, I I 3.

19 Until I926 Britain, France, Italy and Japan always enjoyed representation on the Economic and Financial committees of the League. Thereafter, they were joined by Germany (which left in I933/34) and the USSR, which was granted a permanent seat on the Council in I934. Italy was left unrepresented on the committees once it had left the League in I937. Japanese delegates continued to serve on the committees for some time after Japan's withdrawal in 1933/34.

20 For membership see lists in the Official Journal (Geneva, I920-), I920-I939.

21 Memorandum by Herbert Feis, 'Membership on League Economic Committee I937-I940', I6 Nov. I936, National Archives and Records Administration, College Park, Maryland, United States, RG 59, State Department, Central Decimal File I930-I939 (hereafter NARA), Box 2533, File 4, 500. Cir $199 / 247$. 
EFO's growing size, remit and importance within the League was confirmed at the I927 World Economic Conference, when the Economic Committee was given a fixed statute, limiting its size to fifteen members and tenure to three years. ${ }^{22}$ However, the rotation of its membership was more apparent than real: governments often rolled-over nominations, and representation from the largest states remained the same for over a decade. As the committee primarily focused on trade and commercial policy, its membership reflected the political significance of trade issues. Although representatives were designated as 'independent experts', most governments nominated civil servants, including high-ranking officials from trade and foreign ministries, and economic advisors who straddled a number of ministries and heads of industrial federations. ${ }^{23}$ But while the Economic Committee was quick to grow in membership and reach, sensitivity to encroachment on financial policy remained. The Financial Committee was not granted a formal statute until I937, and throughout its membership remained much smaller than that of the Economic Committee - just ten members whose tenure was for life. ${ }^{24}$ These delegates were either closely affiliated to, or members of, central banks or finance ministries of member countries and of the United States. This arrangement was not without its critics, and membership rules for the Financial Committee were finally committed to statute in I937 with terms of membership finally matching those of the Economic Committee. ${ }^{25}$

A further layer to EFO's work came from the special sub-committees. These were notionally created to address single issues, although in reality they could form a multiplicity of functions - one good example of a special sub-committee was the League of Nations' Gold Delegation. ${ }^{26}$ The committees were of fixed duration and consisted of members from both the Economic and Financial committees as well as specially designated members. (Quite how a special sub-committee investigation was initiated and functioned is a matter of particular interest and will be addressed below.) Special committees also complicate the way in which we might designate the work of the Economic and Financial committees. They liaised with the Council, the Assembly and national governments, and so clearly served as inter-governmental committees, but the special sub-committees frequently included economists and other experts who were not government officials. As a result, special sub-committees worked more as a conduit by which transnational networks of expertise were generated below the

22 Confidential report from Prentiss Bailey Gilbert to Cordell Hull entitled 'The Structure of the League's Economic and Financial Organization. - Projects for Reform of Financial Committee', 7 March i934; NARA, Box 2528, File 2, 500. Ciri98/69.

23 For membership and attendance of the two committees see their reports to the Council printed in the Official Journal, I920-I939.

24 Confidential report from Gilbert to Hull entitled 'The Structure of the League's Economic and Financial Organization. - Projects for Reform of Financial Committee', 7 March 34; NARA, Box 2528, File 2, 500. Ci i $98 / 69$.

25 Here membership could only be for three years, although a certain consistency remained as former members could attend sessions as 'corresponding members'.

26 Patricia Clavin and Jens-Wilhelm Wessels, 'An Idol of Gold? The League of Nations Gold Inquiry and the Great Depression, I929-32', International History Review, 26, 3 (2004). 
level of nation-states between economists based in universities, think tanks and so on. ${ }^{27}$

It is significant that in public the Economic and Financial committees presented themselves as 'independent advisory' bodies of the League. In reality there was nothing independent about them. The word 'independent' simply provided the Council, the Assembly or any national government (whether it was a member of the League or not) with the freedom to reject any unpalatable recommendation that the committees might make. The freedom was guaranteed by the way in which the committees' work interlinked with that of the Council, for Economic or Financial Committee publications had to be approved by the League Council, and, of course, all the committees were publicly accountable. It was very rare, although not entirely unprecedented, that the Council would permit anything contentious to enter the public domain. As a result, the structure of the Economic and Financial committees themselves neutralised any claim to genuine political or intellectual independence, given that both operated as inter-governmental groups whose members' policy positions entirely reflected those of the nation-states which had nominated them. ${ }^{28}$

\section{The role of the Secretariat}

So far, all the elements of EFO we have outlined were different sorts of intergovernmental structures. Nothing, aside from their requirement to report publicly, distinguished the Economic and Financial committees as League institutions. Historians have found it notoriously difficult to discern a distinctive League voice in any aspect of the League's work. But this is partly because they have been listening in the wrong place. It is possible to discern a League perspective in the one aspect of its separate elements, in this case EFO, that was made up entirely of League personnel: the secretariat. EFO's secretariat was in continuous service from 1920 and comprised a dedicated band of civil servants and assorted experts solely in the employ of the League. As with the United Nations today, the advertised purpose of the Secretariat of the League was to furnish the Council and the Assembly, alongside its associated committees, with administrative and technical expertise. The League Secretariat was divided into a variety of services and sections. The former included the Document Services and the Personnel Office and performed straightforward administrative tasks. The role of the secretariats of the different agencies of the League (or sections, as they

27 Some scholars use the terms 'international' and 'transnational' interchangeably. See, e.g., Iriye, Global Community, I. For others, transnationalism implies connections between nation states at sub-state level on a more exclusive basis. See, e.g., articles published under the title of 'People in Motion, Nation in Question: The Case of Twentieth-Century America', Journal of American History, 84, 2 (I997), 524-82. See also the introduction to this theme issue, pp. ooo.

28 There were three further standing committees in EFO of lesser importance - the Fiscal Committee, the Committee of Statistical Experts and the Economic Consultative Committee, designed to ensure the application of the recommendations of the I927 World Economic Conference. (The latter only met twice, in I928 and I929, before its work was subsumed into preparations for the World Economic Conference of 1933). Gilbert to Hull, 'The Structure of the League's Economic and Financial Organization. - Projects for Reform of Financial Committee' 7 March I934, 2 I-22; NARA, Box 2528, File 2, 500. Ci I98/69. 
were known), however, was more complex. In EFO these comprised the Economic Section and Financial Section and, like the other sections that together made up the executive branch of the League (the Legal, Central and Political sections) it was ultimately accountable to the Secretary-General. ${ }^{29}$ The Economic and Financial sections of EFO were served by a number of particularly energetic and able men whose formal function was to provide administrative and technical support to the Economic and Financial committees, the other standing committees and any subcommittees created by the Economic and Financial committees. Officially, the job involved organising the committees' sessions, keeping minutes and providing statistics, other information and expert advice. The Secretariat did not have an advisory mandate, therefore it did not draft reports for the committees and was not entitled to formulate policy recommendations. ${ }^{30}$

Informally, however, things were very different. Very quickly after its creation, the Economic and Financial Section came to attain a significant degree of autonomy that enabled it to shape international economic and financial relations in some hidden and surprising ways. Behind the scenes, the officials of the section began to guide the work of the two advisory committees - the Economic and Financial committees and their sub-committees: by promoting particular resolutions that identified new subjects to be examined, by providing annotated agendas for session meetings, and by drafting almost all committee reports, the vast majority of which contained specific policy recommendations.

As director of the section, the Briton Sir Arthur Salter was a key figure in the early stages. A former civil servant and General Secretary of the Reparations Commission from I920 to I922, he was well connected and experienced. Salter, in common with his successors and many others employed in the sections of the League, had worked in one of the former Inter-Allied war organisations, the Allied war ministries and as a participant in the Paris Conference deliberations. Under his direction, the Economic and Financial Section expanded from seventeen to sixty members of staff in the ten years between I92I and I93I. ${ }^{31}$ When Salter had to be replaced in I93 I, the political bun-fight over who should take over reflected the usual national rivalries associated with assigning any international directorship. It also mirrored the growing importance of the role at a time when the world economy was in crisis. The bitter squabble that resulted was only brought to an end by dividing the Economic and Financial Section into two components: now there were two directors of two sections. ${ }^{32}$

29 See Wertheimer, International Secretariat, chs. VI and VII.

30 Ibid., I 8.

31 This number includes auxiliary staff (typists, translators, clerks, etc.) and members of section, the professional level of civil servants, including economists, statisticians, etc.

32 Strictly speaking, Pietro Stoppani should have replaced Salter because he was the most senior official of the Economic and Financial Section. However, Britain and France opposed the move, arguing that there was already a considerable number of Italian directors of section, and the onset of the Depression underlined the importance of and the interest in the work of EFO. One option was to replace Salter with another Briton, but some League officials and the French government did not want to see another Briton in charge of an entire section, especially given recent 'radical' developments in British financial policy. As a result the secretary-general, Sir Eric Drummond, opted to split the section and 
By October I93 I, the EFO secretariat consisted of the Economic Section and the Financial Section, which had attached to it the pioneering Economic Intelligence Service (EIS), a landmark institution that generated economic and financial data still widely used today. ${ }^{33}$ The British economist and statistician Alexander Loveday directed the Financial Section, while the former Italian member of the Reparations Commission, Pietro Stoppani, led the Economic Section. ${ }^{34}$ Logically enough, the Financial Section served as the Secretariat to the Financial Committee and its subcommittees. ${ }^{35}$ In the years between I93 I and I937, the Financial Section was made up of between fifteen and eighteen members, some on permanent contracts and others serving on a temporary basis, with up to three experts seconded to boost the section's expertise on specific issues when the need arose. The list of officials and experts included some well-known contemporary economists, such as Gottfried Haberler, Jan Tinbergen and John Bell Condliffe, as well as men who would become famous in later years, such as Ragnar Nurkse. ${ }^{36}$ The EIS was an important part of its work, expanding in both size and significance during the I930s, an achievement that can be attributed directly to Loveday. ${ }^{37}$

Given that much of EFO's early work in the I920s had been on questions relating to financial stability, it is hardly surprising that the Economic Section, which served as the secretariat to the Economic Committee, began life as a much smaller unit than the Financial Section. ${ }^{38}$ It comprised between three and five permanent members, with an additional four experts on temporary secondment. It is also worth noting the heavy British representation in the sections. In 1936, of the nineteen nationalities represented in a section totalling twenty-eight members, four were British (including of course the leader of the Financial Section Loveday). There were one Canadian,

to place Joseph Avenol, the French deputy secretary-general, in a co-ordinating position above the two directors. See note from the 'Délégation de la Republique Française' to the Foreign Minister, 29 April I930; Archives du Ministère des Affaires Etrangères, Paris (hereafter Quai d'Orsay), Serié SDN, no. I64, Secretariat, Directeurs de section, I922-I939. With the onset of war in I939, increasing member state defection and a considerable reduction of the League's budget and staff, the sections were reunited and combined with the secretariat of the Communications and Transit Organisation. The new body was called Department II: Economic, Financial and Transit Department, and was headed by Loveday, while Stoppani retired. During the crisis in summer I 940 the bulk of this body migrated to Princeton, New Jersey, from where it continued to work throughout the war until I946. For a contrasting view see Wertheimer, International Secretariat, I I I-I2.

33 EIS, the main statistical agency of the League, had also previously been part of the Economic and Financial Section.

34 Stoppani had been a member of the Italian delegation and served on the Reparations Commission until I923. He jointed the Section in I922. After the Second World War, he was director of the Bank for International Settlements. Loveday worked as a university lecturer in economics, joining the War Office in I9I5. In I9I9 he became a Secretariat official and worked for EFO until I946.

35 Wertheimer, International Secretariat, I I 3.

36 See Gottfried Haberler, Prosperity and Depression (Geneva: League of Nations, I937); Jan Tinbergen, Statistical Testing of Business Cycle Theories, 2 vols. (Geneva: League of Nations, I938 and I939); J. B. Condliffe, Markets and the Problem of Peaceful Change (Paris: International Institute of Intellectual Cooperation, I938); Nurkse, International Currency Experience: Lessons of the Inter-war Period (Princeton: League of Nations, I944). See also staff list in the Official Journal, October I93 I-October I937.

37 Gilbert to Hull, 'The Structure of the League's Economic and Financial Organization. - Projects for Reform of Financial Committee', 7 March 34; NARA, Box 2528, File 2, 500. Ci i 98/69.

38 Wertheimer, International Secretariat, I I4. 
one Australian and one New Zealander, who frequently shared the British viewpoint; in comparison the grand total of French representation in EFO was two. Throughout most of the I930s, two British and two French officials, each from their respective trade or finance ministries, were temporarily seconded to either or both of the sections as specialist advisors. Many of these experts were, or came to be, leading figures in their field. Individuals worthy of note here include Réné Marie Fréderic Charron, Godfrey Isaac Howard Lloyd, William Harpham and James Edward Meade. ${ }^{39}$

A crucial indicator that both the Economic and Financial sections were acting beyond the official remit of their role to provide technical support to the Economic and Financial committees was the huge range of statistical publications and economic studies they produced. These represented the very first sustained collations of internationally comparative economic data and information. They included the Statistical Yearbook of the League of Nations, the Monthly Bulletin of Statistics, Money and Banking, the Review of World Trade and the World Economic Survey. (Many of these series were taken over by the United Nations.) These compilations were supplemented by annual reports on the general economic situation published under the name of the General Secretary - a practice initiated by Joseph Avenol in I936 - that were drafted entirely by the Economic and Financial sections. These sections also published reports on specific topics, including, for example, the study of international trade in primary materials published in I939. ${ }^{40}$ This practice increased during the late I930s and during the Second World War, when many of the League's other activities, notably with regard to disarmament, went into a rapid and ignominious decline. ${ }^{41}$ Officially, of course, the sections did not have the authority to make policy recommendations, but liberal economic values and a variety of suggestions were embedded in its published studies nonetheless. EFO's determination to shape the development of policy through publication was even more apparent in the League's forays into economic thought that included the publication of Gottfried Haberler's groundbreaking Prosperity and Depression in $1936 .{ }^{42}$

\section{How the League worked}

The Second Committee was the third and final distinct component of EFO and served as its linchpin, connecting the Economic and Financial committees and their

39 See staff list in the Official Journal, October I93 I-October I937. Charron was a temporary expert in the Financial Section between I934 and I938. In I939, when the EFO sections were reunited, he was made Director of Economic Questions. Harpham, an official from the British Department of Overseas Trade, was a temporary specialist in the Economic Section between I937 and I938. Lloyd was from the Treasury and worked for Stoppani in I936 and I937.

40 League of Nations, International Trade in Certain Raw Materials and Foodstuffs by Countries of Origin and Consumption, 1935-1939, Geneva, I939.

41 See, e.g., League of Nations, Trade Relations Between Free-market and Controlled Economies (Geneva, I943); League of Nations, Quantitative Trade Controls: Their Causes and Nature (Geneva: I943); and Folke Hilgerdt, The Network of World Trade (Geneva: League of Nations, 1942) and Industrialization and Foreign Trade (Geneva: League of Nations, I945).

42 Gottfried Haberler, Prosperity and Depression. A theoretical Analysis of Cyclical Movements, Ist edn (Geneva: League of Nations, I936). 
respective sub-committees and sections to the main political elements of the League the Assembly and the Council. ${ }^{43}$ While the Covenant of the League attributed the Council more responsibility, especially in the political field, the Assembly quickly became the primary decision-making organ of the League. Strictly speaking, it was the Assembly that decided which issues were to be addressed by the Economic and Financial committees or distinct sub-committees, supported by the work of the Economic and Financial sections. The Assembly made its requests known by debating and then passing resolutions that embodied this will. Because of the size of the Assembly and the complex range of issues before it, however, this took place in one of the six sub-committees of the Assembly that addressed a particular topic area, leaving the plenary sessions free to get bogged down in the big political questions. ${ }^{44}$ These sub-committees were numbered in utilitarian fashion, and it was the Second Committee which was responsible for dealing with economic and financial questions. Like the Assembly, it too had only one public session, held in September each year, and its membership comprised member states' representatives who were nominated by their national delegations in the general Assembly. Once again, however, the pressures of open diplomacy meant that debate in the Second Committee was kept to a bare minimum. Delegates preferred to give lengthy speeches that sought to vindicate their national economic and financial strategies rather than address the state of the international economy more broadly defined, or, indeed, to debate the value of any particular economic or financial policy. The real impetus to EFO's work came only at the end of the speechifying ritual, when particular delegations would put forward resolutions which, with Council support, would authorise the relevant EFO committee to continue their examination of a particular issue under review, or embark on the study of a new topic.

So, with all the distinct components of EFO now outlined, we are in a position for the first time to appreciate how the institution worked in the round, and to discern where real influence lay. (The pattern is applicable also to the Organization for

43 The Assembly convened every September and consisted of delegates from around sixty member states, each of which had one vote. The delegations comprised no more than three representatives plus deputies and technical advisers for the Assembly committees. The general Assembly sessions were open to the public. The League Council consisted of three to six permanent member states and between four and eleven elected member states which were usually represented by foreign ministers. It convened between three and four times annually. The original permanent members were Britain, France, Italy and Japan. During their temporary League membership Germany (I926-I933/4) and the Soviet Union (I933/4-1939) also became permanent members. Only Britain and France remained permanent members throughout the history of the League, as Italy and Japan defected in the I93os. See A. LeRoy Bennet, International Organizations. Principles and Issues, 5 th edn (New Jersey: Prentice Hall, Englewoods Cliffs, I99I), 26, 29-30; Margaret E. Burton, The Assembly of the League of Nations (New York: Howard Fertig, I974 [I94I]), 96-7.

44 Between 1922 and 1938 the League Assembly had six committees. The First Committee dealt with constitutional and legal questions, the Third Committee was occupied with the reduction of armaments and the Sixth Committee with political questions. Only two committees dealt with functional or 'technical' issues: the Fifth Committee on social and humanitarian questions and the Second Committee. Burton, Assembly, I 37. 
Communication and Transit, which included agencies responsible for the Mandates and Intellectual Co-operation, and the Health Organisation, which also liaised with committees addressing the Traffic in Dangerous Drugs and the Protection of Children and Young Persons.) By I93 I, the Economic and Financial Organisation had evolved considerably from its inception ten years previously. It now comprised three main components: a group of standing committees, at the core of which stood the two permanent advisory committees (the Economic Committee and the Financial Committee), plus several ad hoc sub-committees for special subjects; two sections of the Secretariat - the Economic Section and the Financial Section; and the Second Committee of the Assembly. The main task of these distinct yet interlinked components was to generate advisory reports and policy recommendations and supporting statistical information on a variety of pressing economic and financial issues for the Assembly, member and non-member state governments, and the general public.

The system by which these three components interacted can be reduced to a cyclical procedure of five steps, repeated annually and evolving around the regular Assembly sessions in September. First, at its September meeting the Second Committee would begin its discussions based on the previous year's reports from the Economic Committee, the Financial Committee and their sub-committees. The national delegations would then propose and eventually agree on resolutions recommending a particular subject or set of subjects to be studied by the Economic and Financial committees. The Second Committee would ask the Council to authorise the Economic and Financial committees to continue an inquiry, to begin a new inquiry and/or to appoint a new special sub-committee. Second, depending on the subject to be studied, the Economic or the Financial Committee decided the method of the inquiry and who would undertake it. In other words it was decided whether the topic fell solely within the purview of one of the committees, whether it would be better addressed by both the committees in a joint session, or whether a sub-committee should be specially created comprising representatives from both committees and experts seconded from outside. The third step was for the designated committee to get to work, officially drawing only on extensive technical support afforded by the relevant sections of the Secretariat, but in practice, as will be demonstrated, drawing on a considerable range of ideas and advice outside them. The fourth step, after any relevant data had been examined and discussed, was, of course, to write a memorandum. At this stage unanimity became crucial. Because of the universal nature of the League, it was deemed essential that the Economic and Financial Committee reports had to be agreed unanimously, or at least there had to be unanimity among the representatives of the primary League member states. Once this hurdle was overcome, the report was submitted to the Council and, with the latter's consent, published. The fifth and final stage of the cycle came in two arenas, the former far less easy to evaluate than the latter: in the public sphere where national governments, the press, interest groups and the public at large received, and in theory, formulated some kind of response to the report; and in the Second Committee which used these reports as the basis of the next year's discussions, 


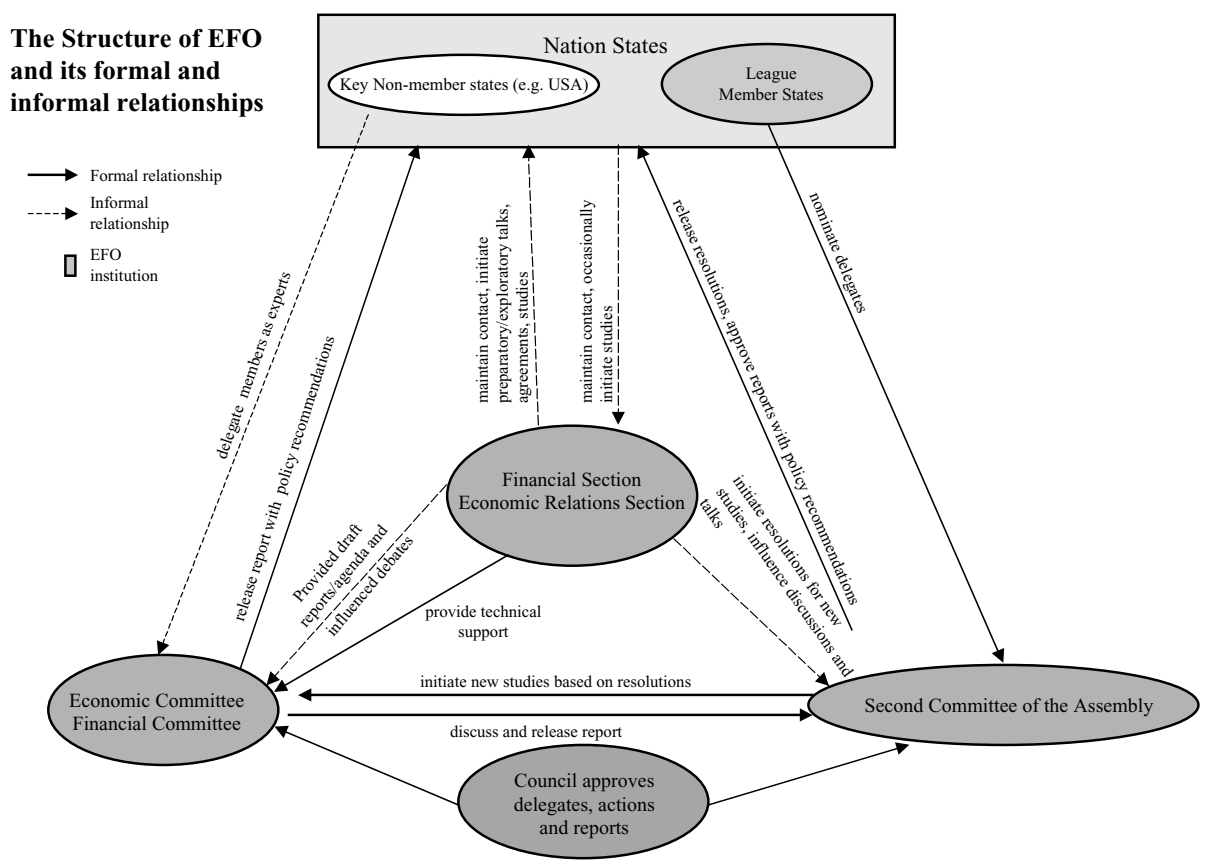

leading to new resolutions, possible policy advice and further studies by EFO (see Figure I). ${ }^{45}$

Laying bare this cyclical pattern of work reveals, for the first time, two key characteristics of EFO's work that were replicated across the entire framework of League activities. First, although the Second Committee served as the formal directing body of the League, the real power lay with the Economic and Financial committees. (This pattern was replicated across the other five sub-committees of the Assembly.) They generated the resolutions adopted by the Second Committee which drove EFO's work forward. Second, the Economic and Financial sections played much more than a technical, supporting role. The Secretariat was involved in each and every stage of the five-step process. It was able to exploit its position precisely because the rules and procedures governing the work of EFO were opaque (many of the national representatives in the committees were unsure of the conventions governing their work), and the internal process by which the League generated policy advice diffuse. The role of the permanently operating Economic and Financial sections, comprising dedicated and experienced League officials, played a central role in shaping League initiatives, advisory reports and policy recommendations at every stage of their development. Indeed, EFO's structure allowed a variety of individuals and ideas to make an impact - it was certainly not nearly as hierarchical as a traditional

45 This reconstruction is based on our detailed studies of the League archives relating to particular economic investigations conducted in the I930s. For a preliminary guide to the evidence see below. 


\section{The League}

\section{Organization of the League of Nations}

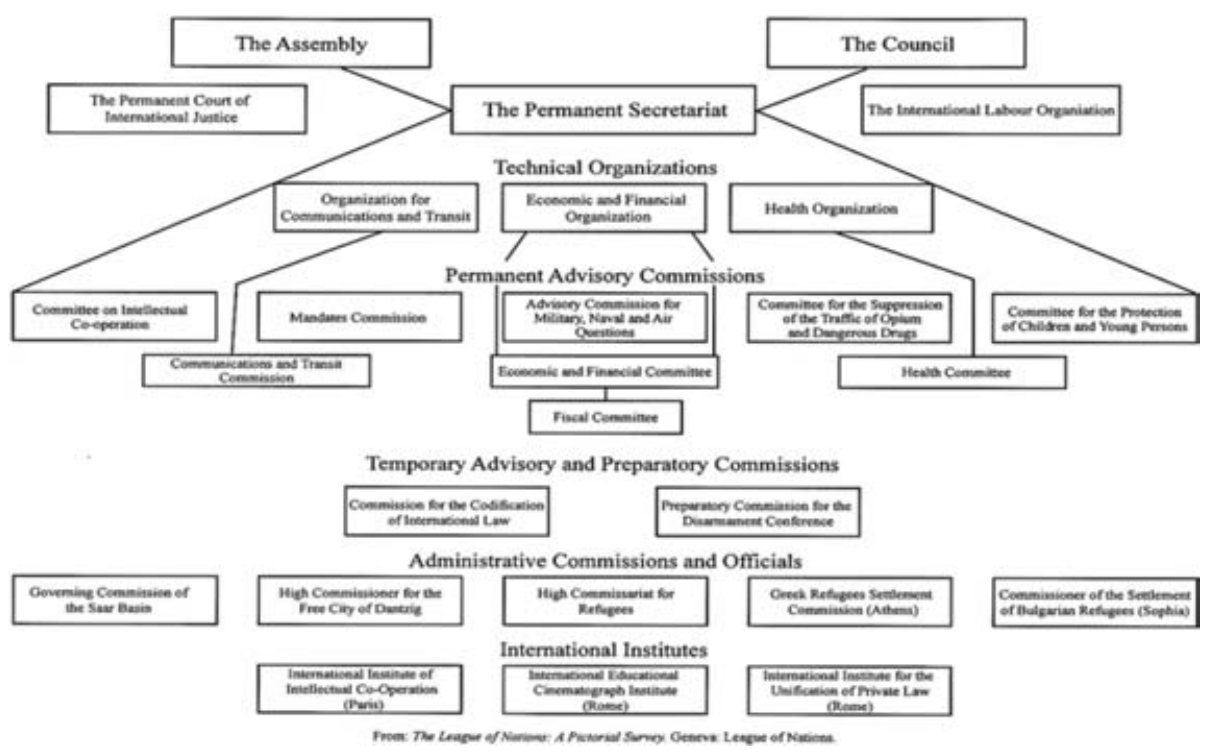

schematic of the League's work would have it. It also meant that informal connections between the different bodies and their personnel became central to EFO's work.

\section{Putting EFO to work}

Three distinct actors - member states, the Secretariat and influential non-members who were accorded a special status, most obviously the United States - sought to exploit EFO in both an 'offensive' and defensive capacity. The 'offense' (in the American sense of the term) came in their efforts to use EFO to advance certain policies or issues that were of particular concern; the defence was necessarily triggered when a member or influential non-member (or groups of members) or the League itself (embodied most obviously by the Secretariat) believed itself to be under attack or threatened by such an initiative. During the I930s, the work of EFO increased as the decade wore on, in sharp contrast to the moribund character of the League's more eye-catching political work. Our particular concern here will be the 'offensive' or pro-active work of the Secretariat and the Economic and Financial sections, which raised a whole series of seemingly 'technical' issues in order to encourage the Economic and Financial committees and the Second Committee to address directly contentious topics of high policy. In this sense we seek to challenge Pauly's characterisation of EFO's work during the period as 'increasingly analytical and 
decreasingly practical'. ${ }^{46}$ In the mind of the EFO secretariat, the two elements were closely interwoven. During the I930s the Economic and Financial sections sought to advance international co-operation on a range of pressing economic and financial issues - including the character and impact of clearing agreements, the viability of the gold standard, the ever rising levels of international protectionism, the causes of the Great Depression and the means by which another might be averted. In EFO's mind, analysis was not divorced from practice. Rather it, rather naively, believed that the better its analysis, the greater the chance of policy co-ordination between the world's great democracies.

In the wake of the World Economic Conference of I933, Loveday and Stoppani agreed that the Economic and Financial sections should place the rising levels of international protectionism at the forefront of its concerns. The reasons for this emphasis on trade were manifold. It was not just because of the failure of the League Gold Delegation of I93 I or the bitter fall-out over negotiations for the notorious Temporary Stabilisation Agreement which ostensibly scuppered the conference. The secretariat's calculation was strongly influenced by the new direction in US internationalism and the view that trade liberalisation was the best available route to address rising political nationalism. Loveday and Stoppani took their lead from the US Secretary of State Cordell Hull's overtures regarding the planned Reciprocal Tariff Agreement Act (RTAA) made at the World Economic Conference. In I934 the RTAA passed into law and by 1945 the United States had signed trade deals with twenty-nine countries, reducing the US tariff by nearly three-quarters. The RTAA is associated with the development of US trade with Latin America, but Hull had first hoped to use the RTAA to secure agreements with the European powers (his first target was Britain). When his early hopes were dashed he, and the departments of State and Commerce, turned their attention to Latin and South America instead. ${ }^{47}$ EFO believed that by adopting a similar approach to the United States to trade protectionism it would bind the United States more closely to the heart of its work, and would prompt members of the Economic Committee, under whose remit the initiative fell, to stay focused on the crippling and varied effects of international protectionism.

The strategy underpinning the efforts of the Economic and Financial sections was the aspiration that the Economic Committee would consent to publishing in the League's name one of its far-ranging draft reports on trade protectionism that contained within it practical and constructive policy proposals for tariff and quota reductions. Such a step, Loveday - who, though director of the Financial Section, was as much a driving force behind the initiative as Stoppani - calculated would push national delegates in the Economic Committee and the Second Committee into

46 Pauly, 'League of Nations', 20, 26, 27. Ghebali, too, claimed that the 'League functional bodies played no significant role during the Depression', Ghebali, 'League of Nations and Functionalism', I52.

47 Patricia Clavin, The Failure of Economic Diplomacy: Britain, Germany, France and the United States, 193136 (Basingstoke: Macmillan, I996), I43-I 53; Walter LaFeber, The American Age. United States Foreign Policy at Home and Abroad Since 1750 (New York: W. W. Norton, I989), 356. 
discussing fundamental problems of international economic and eventually monetary relations. They hoped for more than talks. Loveday and Stoppani believed that discussions in the Second Committee, which was part of the Assembly, would lead to a series of bilateral or, even better, multilateral international trade reductions under the auspices of the League. Trade protectionism was also seen as a route to addressing sensitive issues surrounding the malfunctioning gold standard too. In this sense, the Secretariat officials viewed the Second Committee sessions as something of an annual mini economic and financial conference.

Each year from I933 until the outbreak of war in I939, every agenda drafted by the Economic Section for the annual sessions of the Economic Committee included a heading under which fundamental problems bedevilling the world's economy were discussed. The title of this heading may have varied a little from year to year, but the primary focus of the talks, as the lucid and well-informed preparatory materials for the discussions compiled by the section makes clear, were the latest troubling trends in commercial policy and their relationship to financial issues. ${ }^{48}$ From I 933 to I936, the materials presented and the subsequent discussions centred on the essential policy differences between the Gold Bloc and debtor countries (France, the Benelux states, Switzerland, Poland and other east European states) on the one hand, and the dollar and sterling bloc countries (Britain, its dominions, the Scandinavian states and the United States) on the other. While the League officials saw the Economic Committee as the vehicle by means of which they believed they could influence delegates in the Second Committee, the Financial Committee remained deliberately on the sidelines. Member states still on the gold standard, notably of course France, were especially sensitive to any attempt by Britain and the United States (countries with floating currencies), in particular, to discuss monetary policy in a public forum. Here the structure of EFO's work afforded some protection, for when the Economic Committee touched on monetary issues, it was forced to consult the Financial Committee, whose orthodox members worked either to water down or to block

48 The mandate for these general discussions was taken from the I933 World Economic Conference. For each annual session report, the Economic Committee used a different title for this item: in I933 it was simply called 'General Considerations'; in I934 it was 'Exchange of Views on the General Position of International Economic Relations'; in I935 'International Economic Relations'; in I 936 'The Present Phase of International Economic Relations'; in 1937 'State of International Economic Relations'; in 1938 'General Observation', and in I939 'International Economic Relations'. See the reports of the Economic Committee in the Official Journal, I933-9. Other bland headings in final reports also covered up where discussions had touched upon contentious economic problems. These included, e.g., 'The Unification of Customs Nomenclature', 'Customs Formalities', 'Export and Import of Meat and Meat Preparations', or 'Commercial Propaganda'. See the informal agendas for I933, I934, I935 and 1937 of the Economic Committee drafted by the Secretariat and forwarded by Prentiss Gilbert to Hull: NARA, Box 2532, 500. Cirig/io9; 500. Cirg9/i29; 500. Ciri99/I39; Box 2534, 500. Ci I 99/270. See notes by the Financial Section: 'Note on Factors important to Monetary Policy', 20 Oct. 1937, Archive of the League of Nations, United Nations Library, Geneva (hereafter LN), R4620, IoC/3 I I69/3 I I69. For the US view, see Gilbert to Hull, 'Financial Committee - Interview with Mr. Loveday', I 3 Nov. I937; NARA, Box 2529, File I, 500. Ciri98/I25. 
entirely, draft reports prepared by the sections before they were even seen by the Economic Committee. ${ }^{49}$

While the Economic and Financial sections' strategy drew a blank in I933 and I934, ${ }^{50}$ in I935 and again in I936 Stoppani and Loveday managed to persuade the Economic Committee to agree on and submit a report to the Second Committee which would trigger wide-ranging discussions on international protectionism. It is clear that the secretariat was the chief instigator in this process, its members working tirelessly behind the scenes to bring together opposing views. There were plenty of these as a possible devaluation of the French franc became a potential complication, although, as far as League officials were concerned, it was also an opportunity. ${ }^{51}$ In 1935 the Economic Section, with Loveday's help, drafted a report addressed to leading governments that sought to reconcile differences in British, French and US monetary and commercial policies. Central to the initiative was Washington's new commitment to bilateral and ultimately multilateral trade reductions based on the most-favoured-nation clause and Io per cent tariff reductions. This shaped the Secretariat's approach and it flooded Economic Committee members with

49 This triggered some tension between the two directors, Stoppani and Loveday. In the later I930s, Loveday and his colleagues desperately tried to get the conservative 'experts' of the Financial Committee to address more important issues. See, e.g., Rowe-Dutton to Leith-Ross, I Oct. I935, Public Record Office, London (hereafter PRO), Records of the Treasury (hereafter T) I88/I20. See also Report by Dayras (French member of the Financial Committee) to the Président du Conseil and the Ministre des Affaires Etrangères, 7 Sept. I935, Quai d'Orsay, Série SDN, no II7I, IJ Questions Economiques, Organisation Economique et Financière, Comité économique. - 5I à 68ème session, I9I I-I939; Leith-Ross to Niemeyer, I2 Sept. I936, PRO Ti88/I20; report of the Economic Committee, 'Remarks on the Present Phase of International Economic Relations - Reconstruction of the Machinery of International Exchange as a Factor in Recovery and Appeasement - Together with Observations by the Financial Committee', League of Nations, Geneva, I4 Sept. I936; the Secretariat's draft of the report sent to the Quai d'Orsay entitled 'Comité Economique - Rapport du Comité Economique au Conseil sur l'Etat Actuel des Relations Economiques Internationales', I4 Sept. I936, Quai d'Orsay, Série SDN, No I399, IJ - Questions Economiques et Financières, Politique commerciale, Mai I933-Juin I939; Dayras to the Quai d'Orsay, 5. Dec. I937, Quai d'Orsay, Direction des Affaires Politiques et Commerciales, no. 658, Y-serié, carton 86, Société des Nations, Comité Financier (questions générales), I932 8 mars-I938 8 mai.

50 See Secretariat notes 'Exchange of Views on Present Conditions of Trade' and the 'Most-Favoured Nation Clause', NARA, Box 2532, File I, 500. Cirg9/ro9, June I933. See also Secretariat note entitled 'Main Points for the Discussion of Present Conditions in International Trade (Item I of the Agenda of the 4Ist session of the Economic Committee)', I2 July I934, I3. NARA, Box 2532, File I, 500. Ci i99/I29.

51 While the representatives of the gold bloc countries led by France insisted on monetary stabilisation as a prerequisite for any reduction in quantitative trade restrictions (primarily quotas), British and US members firmly held the opposite view. They were pressing for a reduction of import quotas, and opposed any de jure currency stabilisation. See James Harvey Rogers, 'Proceedings of the Economic Committee of the League of Nations', 2-7, undated, attached to letter Cavender (Rogers' secretary) to Feis, I 8 May I935, NARA, Box 2532; Leith-Ross report on Economic Committee meeting sent to Ashton-Gwatkin, 7 May I935, PRO, General Correspondence of the Foreign Office (hereafter FO37I) I9680/W4008; Hull to Gilbert, 2 May I935, and Gilbert to Hull for Morgenthau, 3 May I935, NARA, Box 2532, 500. Cir99/I37A and I38; Gilbert's report to Hull, '42nd Session of Economic Committee of the League of Nations', 3 I May I935. NARA, Box 2532, 500. Ci I99/I44; Economic Committee, 'Report to the Council on the Work of its Forty-Second Session', Geneva, 7 May 1935 , in NARA, Box 2532, 500. Cir $99 /$ I29. 
preparatory memoranda outlining in detail the new US commercial policy based on the pioneering RTAA. Their efforts in committee meetings were supported by leading US representation, including Herbert Feis, Leo Pasvolsky, James Harvey Rogers and Martin Hill. ${ }^{52}$ It also proposed multilateral negotiations, which would include a currency agreement designed to moderate currencies between the main economic powers. ${ }^{53}$ These efforts culminated in a secret joint meeting between members of the Economic and Financial committees in Paris, where it was agreed to release an Economic Committee report on the general economic problems. ${ }^{54}$

The public presentation of this diplomacy betrayed little of the far-reaching discussions that had taken place in private. While the Secretariat's enthusiasm for a Hullian programme of trade liberalisation generated some heated and frank exchanges, its proposal for a reduction in trade restrictions extended on the basis of the most-favoured-nation clause and supplemented by a new currency stabilisation agreement was rejected by the national delegates. This was an outcome that especially frustrated the United States. As the US consul in Geneva noted, the published Economic Committee report was 'absolutely noncommittal and completely unenlightening as to the trend of the debates'. ${ }^{55}$ The report appeared to be nothing more than a fairly general condemnation of the continued harm done by international protectionism to economic, financial and political relations and made no mention of the secretariat's policy recommendations. ${ }^{56}$ The best the League officials were able to achieve in the report was a clear call for the return to an open world economy. They crossed their fingers and hoped it might serve as a useful basis for discussions in the Second Committee. They did not rest on their knotted digits, however. Stoppani also hosted secret talks between British and French officials,

52 For a more detailed assessment of US participation, see Patricia Clavin, 'Internationalist Minds in Nationalist Bodies: the United States and the League of Nations, I933-40', paper presented to the Society of Historians of American Foreign Relations, Austin, Texas, 2004.

53 Avenol and Loveday went to London to prepare the British for discussions in the Second Committee, while Stoppani was in close contact with Paris See Stoppani to Massigli (Sous-Directeur de la Société des Nations - Ministère des Affaires Etrangères), 23 Aug. I935, Quai d'Orsay, Serié SDN, no. II54, IJ - Questions Economique, Organisation Economique et Financièreuvre économique et financière de la SDN, I930-I936; Strang minute, I2 July I935 and Leigh-Smith to Treasury, 25 July 35, PRO FO37I/I960I/W640I/3I/50; Stevenson minute on talk with Loveday, I9 Aug. I935, PRO FO37I/I960I/W7333; Leigh-Smith letter to Treasury, Board of Trade, India Office, Colonial Office, and Dominion Office, 27Aug. I935, PRO FO37I/I960I/W7333/3I/50.

54 For disputes as to what should be published, see Rowe-Dutton to Leith-Ross, I Oct. I935, PRO Ti88/I20; report by Dayras to the Président du Conseil and the Ministre des Affaires Etrangères, 7 Sept. I935, Quai d'Orsay, Série SDN, no II7I, IJ - Questions Economiques, Organisation Economique et Financière, Comité économique. - 5I à 68ème session, I9I I-I939.

55 Gilbert to Hull, 'Report of the Economic Committee on the Work of its Forty-first Session', Io Sept. I934, NARA, Box 2532, File I, 500. Cir 99/I28. On the September 1935 session of the Economic Committee see Rowe-Dutton to Leith-Ross, I Oct. I935, PRO Ti88/I20; Rogers' report entitled 'Proceedings of the Economic Committee of the League of Nations - Forty-Third Session - Geneva, September I935', attached to Gilbert's report to Hull entitled 'Forty-Third Session of the Economic Committee of the League of Nations', i 8 Sept. I935, NARA, Box 2532, 500. Ciri99/i65.

56 See Economic Committee, 'Remarks on the Present Phase of International Economic Relations', Geneva, I3 Sept. I935. 
but the Economic and Financial sections' hopes were dashed. The talks failed to make the hoped for breakthrough. ${ }^{57}$

Mere cajoling by the Secretariat simply was not enough to effect progress. The EFO secretariat had no power other than reasoning to secure co-operation, and US support at this stage was not enough in the face of French indifference and strong British opposition, an opposition that throws into question the dominance over the League with which Britain is usually credited. The British government certainly was in no doubt as to US support for the League initiative. But, as a Foreign Office memorandum put it, trade liberalisation 'is not a promising line of advance.... although its [the League's] economic activities receives a considerable measure of collaboration from some member states'. ${ }^{58}$ The Treasury and the Board of Trade, in particular, were strongly of the opinion that trade liberalisation would bring neither economic gain for Britain (in contrast to the introduction of Imperial and General Tariff schemes) or do much to meet the demands of German and Italian diplomats.

Rather than drop the issue, the Economic Section redoubled its efforts in I936, a year when the League's prestige had been heavily battered over the termination of sanctions against Italy. Using the wide variety of governmental and expert contacts generated over years of work, Stoppani put as much pressure as he could muster on Britain, France and the United States to agree that the 1936 meeting of the Economic Committee should sponsor a five-power conference (Britain, France, the United States, Germany and Italy) to negotiate an ambitious, all-embracing economic and financial agreement. The Secretariat officials proposed a preliminary economic agreement between the United States, Britain and France on the one hand, and Germany and Italy on the other as a prelude for a possible political settlement. Britain and the United States, countries with the most powerful currencies and the least economic and financial (but not political) constraints, should take the first step by agreeing to stabilise their currencies for a fixed period of time, while the gold bloc countries would devalue their currencies to relieve the deflationary pressures on their economies. The next step was for Britain and the United States to extend debt, credit and trade concessions to Germany, Italy and the smaller countries of central and south-eastern Europe to encourage them to abandon their extensive network

57 See Burgin to Phillips, I8 Sept. I935, PRO FO37I/I960I; Gilbert to Hull, 'Speech by French Minister of Commerce before the Second Committee of the Assembly of the League of Nations', 20 Sept. I935, NARA, Box 2480, 500. Ci I I/89I; Bonnet speech at Second Committee, I 7 Sept. I935, PRO FO37I/I960I/W8767/3I/50; Quai d'Orsay, Serié SDN, no. ioi, ASSEMBLEE, Seizième Session, Mai I935-juillet I936; Rowe-Dutton to Leith-Ross, I Oct. I935, PRO Ti88/I20; notes of meeting of Commonwealth delegates, I 8 Sept. I935, PRO FO37I/I960I/W8338; Waley minute to Hopkins, 20 Sept. I935, PRO, Records of the Board of Trade, I I/375; Records of the Sixteenth Ordinary Session of the Assembly - Meetings of the Committees - Minutes of the Second Committee (Technical Questions), Official Journal, Special Supplement, No. I40, Geneva, I935.

58 Memorandum by Makins, 26 May I938, 6, PRO FO37I/225Io/W6794; memorandum by Howard Bucknell, 23 Aug. I938, NARA, Box 2472, File 2. 
of currency and trade controls, thereby reintegrating them into the international economy. ${ }^{59}$

In July I936, in secret meetings with British, French and US statesmen, Stoppani outlined the key advantages of a League sponsored initiative: first preparatory negotiations between their countries and the League would take place in private sessions of the Economic Committee - their work would only become public when a report was published. Second, because the Economic Committee was officially a League body comprising 'independent experts' nominated for their expertise and not necessarily because of their political authority, the Economic Committee would appear as the initiator of the project. This meant that if the initiative failed, Washington, Paris and London would not be held responsible and could avoid any unnecessary embarrassment or domestic opposition that might result. The principal intention was to publish a further report which would outline the framework of the potential agreement between the democracies - a report authored in the first instance by the Economic Section - which would serve as the basis for a second round of discussions in the Second Committee on the main economic problems. Only after this would meetings between key nation-states be necessary and these could be held within or outside the auspices of the League, whichever key governments preferred. $^{60}$

It is easy to condemn the Economic Section's naivety. Given the absence of political will and the complexity of the issues under discussion, the process outlined was likely to take months if not years. The pace and aggression of German, Italian and Japanese foreign policies, given what we now know about them, meant that the League's initiative was little more than waving at windmills. There was no prospect either that the aggressors would rescind their economic controls or that any such settlement would provide the basis for agreement on pressing security issues. In many ways Stoppani's proposal was only a more lucid and direct articulation of much of the thinking that underpinned British appeasement and US foreign policy in the I930s. Rather than coming to some accommodation with the Axis powers, Stoppani had a more limited, but no less significant ambition in mind: an improvement in

59 See Stoppani to Van Zeeland, 3 July I936, PRO FO37I/20474/W6Io9; Gilbert to Hull, 'Confidential - Possible Developments of Discussions on Economic Questions in the Forthcoming Session of the Economic Committee and the Assembly of the League of Nation', I 4 July I936, NARA, Box 2533, 500. Ci I99/202; Walters to Strang, 4 July I936 (6I09) and 7 July I936, notes by Gladwyn Jebb, 7 July I936, PRO FO37I/20474/W6ro9; Eden to Runciman, I 7 July I936, Ti60/633. See also Thompson to Feis, 2 I July I936, NARA, Box 2533, 500. Cirg9/205, Stoppani to Leith-Ross, 27 July I936, PRO, Ti 88/I 48; copy of a memo from Stoppani to Massigli, 22 July I936. For the French version of this, see 'Memorandum en relation avec le discourse de cloture de Monsieur Van Zeeland à la dernière Assemblée de la Société des Nations', 22 July I936, Quai d'Orsay, Série SDN, No I399, IJ - Questions Economiques et Financières, Politique commerciale, Mai I933-juin I939.

60 Stoppani travelled to Paris and London to speak to government officials personally, while Washington was kept informed by the Secretariat. Copy of a letter from Stoppani to Strang, 3 I July I936, Quai d'Orsay, Série SDN, No I399, IJ - Questions Economiques et Financières, Politique commerciale, Mai I933 - juin I939; Stoppani to Halifax, 3 Aug. I936, PRO, Tr88/I48; Thompson to Feis, 6 Aug. I936, NARA, Box 2533, File 2, 500. Ci I99/2 I 7. 
British-French-US economic and financial relations which had been in sustained difficulties since I93 I.

Our purpose here, however, is not so much to assess the feasibility of these policies as to draw out the degree to which the League, and by this we mean the officials and agencies of the League, took the lead as far as it was able given the structure of the institution, and how EFO sought to exploit 'functional' or technical issues to address questions of high politics. Stoppani made it clear from the outset that the economic scheme was intimately connected with the League's and nationstates' wider responsibility to maintain peace and international security. Economic rapprochement was to form the basis of a general political settlement. ${ }^{61}$

From the perspective of trying to understand the Economic and Financial sections' evolving place in the architecture of the international political economy, the plan marked a significant step forward in both the ambition of the sections' leaders and their conviction that technical issues relating to trade and currency could shape the broader political climate. Not only did Loveday and Stoppani use the official organisational structure and procedures of EFO to put forward what they considered to be an appropriate policy route out of the deadlock in international economic relations; they also used all the informal means at their disposal, be it through private meetings with key figures in Geneva and in other capital cities of the world or through the production and dissemination of memoranda and supporting data, to shape those relations. Given the political context in which they were operating and the Secretariat's complete lack of 'coercive' powers, it is hardly surprising that the initiative stalled. The support of nation-states was vital if the sections' proposals were to progress.

At the same time, no one power rejected the League scheme outright; instead, nation-states merely expressed a polite disinterest in the 1936 proposal, which meant that it took some time for Stoppani to register that neither Britain nor the United States would abandon their established economic and foreign policies to support the plan. ${ }^{62}$ As a result Stoppani and his colleagues continued to prepare a draft report proposing a five-power conference to address monetary stabilisation and trade liberalisation. ${ }^{63}$ With one eye on its growing financial crisis, France now became an enthusiastic supporter, ${ }^{64}$ and both Britain and the United States sent an expanded delegation to the last Economic Committee session prior to the 1936 Assembly. ${ }^{65}$

61 See document entitled 'Confidential - Memorandum - In Connexion with M. Van Zeeland's Speech at the Recent Assembly of the League of Nations', 22 July I936, PRO Ti60/633; Stoppani to Strang, 'Aide-Memoire pour Conversation avec M. Stoppani', 4 Aug. I936, Quai d'Orsay, Série SDN, No I399, IJ - Questions Economiques et Financières, Politique commerciale, Mai-juin I939.

62 In keeping with later British responses to US efforts to shape economic appeasement in I937, it was Eden who expressed an interest in the proposal, while Neville Chamberlain condemned it outright. Eden to Chamberlain, I2 Aug. I936, Chamberlain note to Fisher and Fergusson, 3 I July I936, Eden to Chamberlain, I2 Aug. I936, Phillips to Fisher, 24 Aug. I936, PRO Tr6o/633, also in Ti88/I48.

63 See, e.g., Stoppani to Massigli, I4 Sept. I936, Quai d’Orsay, Série SDN, No I399, IJ - Questions Economiques et Financières, Politique commerciale, Mai I933 - Juin I939.

64 Stoppani to Halifax, I I Aug. I936, PRO Ti88/I48. 
But, in public, the outcome of the session appeared to demonstrate that little had changed when it came to the tenor of international economic relations. Britain repeated its view that it was not prepared to support any further meetings of an international economic conference (a view it was to repeat in 1937, I938 and I939), since it was unlikely to produce a concrete outcome, merely providing Germany and the other aggressor powers to grandstand and to exploit divisions between the world's remaining democracies. The British government also blocked the inclusion of a proposed world conference in the report of the Economic Committee. ${ }^{66}$

While the League failed to make political headway, the report (with the first draft again authored by the Economic Section) on the Economic Committee's work broke some new ground in the field of economic policy: It articulated the agreed view of the League and all the nation-states present at the meeting that the world should move towards a reduction of trade restrictions combined with a programme of co-ordinated 'currency adjustment' - in other words a devaluation of the gold bloc currencies. Not only was this the first report of the League to propose and endorse currency devaluation as a legitimate policy measure for trade expansion and economic recovery, it was the first time other countries had articulated this view publicly in an international forum - bar the United States' denunciation of the Temporary Stabilization Agreement at the World Economic Conference in I933, a step for which it was roundly condemned. ${ }^{67}$ Moreover, the report set the scene for the upcoming Tripartite Monetary Stabilization Agreement, signed in I936, between Britain, France and the United States: much of the wording of the report was repeated in the text of the agreement, announced eleven days later. ${ }^{68}$ Indeed, covert meetings organised by Stoppani between British and French representatives, to prepare for the forthcoming session of the Second Committee, had acted as venues for negotiations integral to the conclusion of the stabilisation agreement. ${ }^{69}$

65 The British delegation was swelled by the additional participation of Gladwyn Jebb from the Foreign Office, while, more significantly, Leo Pasvolsky, assistant secretary of the State Department, supported James Harvey Rogers, the official US representative on the committee. SeeFeis to Thompson, I8 Aug. I936, NARA, Box 2533, File 2, 500. Cirg9/217, Box 2533, File 2, 500. Cirg9/2i8A; Jebb to Chamberlain, I7 Sept. I936, PRO Ti88/i20.

66 This has been missed by historians of economic appeasement who see proposals for an international economic conference emerging for the first time in I937 or I938. In fact, the idea never went away after the arrest of the World Economic Conference of I933. See Clavin, Failure of Economic Diplomacy, I67-73, I90-20I.

67 See Economic Committee, 'Remarks on the Present Phase of International Economic Relations Reconstruction of the Machinery of International Exchange as a Factor in Recovery and Appeasement - Together with Observations by the Financial Committee', Geneva, I4 Sept. I936. On the session of the Economic Committee see Jebb's detailed notes on 'Proceedings of the Economic Committee with Annexes of the speeches', I7 Sept. I936, PRO Ti88/I20; also 'Remarks made by Sir Frederick Leith-Ross in the Forty-Eighth Session of the Economic Committee of the League of Nations,' undated, attached to Gilbert's report to Hull entitled 'Meeting of Economic Committee of the League of Nations', i 8 Sept. I936, NARA, Box 2533, File 3, 500. Ci I 99/238 I99/238.

68 See Moore to Gilbert, is Sept. I936, NARA, Box 2533, File 3, 500. Ciri99/224; Leith-Ross to Niemeyer, I2 Sept. I936; PRO Tr88/I20.

69 See Gilbert to Hull, i 8 Sept. I936, NARA, Box 2533, 500. Ci i99/230; Phillips to FO, 22 Sept. I936, PRO Ti60/633; note to Treasury from UK delegate on conversation with Stoppani, Playfair to Waley, 
In sum, the enthusiasm and energy of the Economic and Financial sections for discussions on a variety of pressing economic issues in the Economic Committee and the Second Committee resulted in a number of opportunities for informal intergovernmental meetings on major policy issues. These helped to draw out areas of policy convergence and, as we have seen, divergence between key liberal democracies. Despite the coherence of the transnational elite within EFO, without the support of nation-states beyond the walls of its committee rooms, its efforts had limited effects. This did not mean, however, that the League's efforts were wasted. In the short term, EFO helped French policy-makers to legitimise the devaluation of the franc and to articulate a new public commitment to a more liberal trade policy. League engagement in the devaluation of the franc helped to internationalise the process and neutralise some suspicion and resentment about the role of Britain and the United States. In the long term, the epistemic community housed within EFO was to make an important contribution to internationalism during and after the Second World War.

\section{Conclusion}

In this article we have sought to demonstrate why it is important and valuable to differentiate between the various elements of the League of Nations and to clarify the widespread confusion regarding the nature of its committees and sections. All too often the labours of the different League inter-governmental committees have been confused with the work and publications produced by the Permanent Secretariat of the League. Differentiating between these published products alone helps us to explain why some League publications are vacuous and confused (inter-governmental reports produced with a concern for unanimity and reputation uppermost), while others are insightful and sharp (single-authored pieces produced by experts employed by the Secretariat or by the EIS for example). Endres and Fleming are but the most recently published scholars to brand reports published by the League's inter-governmental bodies as publications authored by 'League experts' or 'League economists', when these publications were, in fact, the records of inconclusive or stalled discussions among government representatives. ${ }^{70}$

Therefore it is difficult to speak of the League, or in our case the Economic and Financial Organisation, as acting according to a fixed schema of co-operation,

24 Sept. I936 and 26 Sept. I936, PRO Ti60/633. For the I936 session of the Second Committee and behind the scenes negotiations see the Official Journal, Special Supplement No. 157, Records of the Seventeenth Ordinary Session of the Assembly - Meetings of the Committees - Minutes of the Second Committee (Technical Questions), Geneva I936.

70 They often write of 'Geneva-based ILO-LON economists', although many of the League reports originated from committees comprising government representatives, such as the Delegation on Economic Depressions. League officials, League economists, members of the International Labour Organisation, League committees and delegations comprising national representatives are frequently, and confusingly, lumped together See Andres M. Endres and Grant A. Fleming, International Organisations and the Analysis of Economic Policy, 1919-1950 (Cambridge: Cambridge University Press, 2002). 
be it inter-governmental or transnational, because, in many ways, it was not a coherent body with fixed rules and procedures. The key to understanding the often seemingly abstruse functioning and structure of the League was that its rules and procedures were deliberately kept ambiguous in order to provide the flexibility to pursue political negotiations by a variety of means, frequently under the guise of 'technical' or functional discussions. In this regard EFO and the League as a whole contained elements of both the idealistic and the realistic notions regarding the role of international organisations in the international architecture of the modern world. The structure, functions and procedures of EFO formed a platform that was used variously by member states, important non-member states (in particular the United States), and the Secretariat of the League of Nations. Clearly, the various bodies of the League simultaneously reflected characteristics of autonomy from and dependence on nation states. All of these actors used the organisation to advance, promote, protect and justify their policies by linking apparently functional/technical issues to inter-governmental discussions on fundamental questions that went to the heart of contemporary problems in the political economy; inter-governmentalism and transnationalism interacted.

Where one can most properly detect a distinct 'League voice' is in the work of the EFO secretariat. By I933 it had developed a well-articulated and coherent longterm policy agenda centred on an open, liberal economy, but one which no longer had the international gold standard at the heart of financial policy. (There is much more that remains to be said about the values and ideas that underpinned its policy recommendations for the international political economy.) Unsurprisingly, EFO was also strongly committed to the notion that international economic agreements held the key not just to economic well-being but to political peace. There is also no real evidence to suggest that the nationality of particular advisors dominated their policy perspective. True, Loveday's commitment to an open, liberal international economy was undoubtedly informed and shaped by his British education and professional experience, but it is equally apparent that he was prepared to go against British wishes when it came to promoting international tariff reductions in the I930s. So, too, was Stoppani, who conspicuously ignored Mussolini’s instructions to abandon his post to remain Italy's only high-ranking League official after I936. ${ }^{71}$

At the same time, echoing established assessments of the League's performance, we have underlined that in the short term the structure and procedures governing the work of EFO meant that the real decision-making power continued to rest with member states. The Second Committee had the power to stymie any initiative. Most initiatives made by the EFO sections were blocked easily by member states with expert inquiries all too frequently terminated without members of the informed public ever noticing. Only in rare circumstances, as in the case of the Economic Committee

$71 \mathrm{He}$ exploited his position to encourage moderate forces within Italy while at the same time making the League more aware of the particular economic challenges before central and eastern Europe. When Italy left the League, all Italian League officials were instructed to resign from the Secretariat. Stoppani stayed on until I939. He then fled briefly to Paris, but returned to Switzerland after the fall of France, where he saw out the war working for EFO. 
and Second Committee reports of 1936, did EFO initiatives begin to generate a real consensus among key players that resulted in meaningful policy declarations and agreements. Officials of the Economic Section and the Financial Section were well aware of their comparative impotence and after 1936 actively sought to reform the way in which the institution worked. In I937, when it became clear that the Tripartite Stabilisation Agreement had not produced an improvement in British, French and US monetary and trade relations to which everyone in EFO's sections aspired, the latter began to lobby aggressively for the Second Committee to be reformed. At the heart of their requests to key member states (although they actively involved the United States too) was the desire that EFO be turned into an autonomous international economic organisation. In effect, Loveday, Stoppani and Avenol wanted EFO to attain a similarly independent status to that enjoyed by International Labour Organisation, free of direct Council and Assembly intervention. These reform efforts eventually culminated in the proposals of the so-called Bruce Committee in August I939 and the first attempt in 1940 to create a central guiding organ for the organisation, the stillborn EFO Central Committee. This reform movement is beyond the scope of this paper, although it is worth noting that while the Secretariat desired to uncouple itself from inter-governmental committees that tied it closely to the political fate of the League prior to I940, it was these same intergovernmental connections that put it in such a strong position to shape post-war reconstruction. This examination of how the League worked also draws out the range of divergent expertise drawn into the League's orbit and sustained by twenty years of meetings and publications. In this both the inter-governmental committees of EFO and the Secretariat which supported them generated a network of men, publications, experience and ideas that was to inform and shape the economic internationalism that reshaped the world after I945. 